\title{
Effect of heat and thermosonication treatments on watercress (Nasturtium officinale) vitamin $\mathrm{C}$ degradation kinetics
}

\author{
Rui M.S. Cruz ${ }^{\text {a }}$, Margarida C. Vieira ${ }^{\text {b }}$, Cristina L.M. Silva ${ }^{a, *}$ \\ ${ }^{a}$ Escola Superior de Biotecnologia, Universidade Católica Portuguesa, Rua Dr. António Bernardino de Almeida, 4200-072 Porto, Portugal \\ ${ }^{\mathrm{b}}$ Escola Superior de Tecnologia, Universidade do Algarve, Campus da Penha, 8005-139 Faro, Portugal
}

Keywords: Watercress; Heat blanching; Thermosonication; Vitamin C; Kinetics modelling

\begin{abstract}
The use of ultrasound in food processing creates novel and interesting methodologies, which are often complementary to classical techniques. In this work, the effect of heat and the combined treatment heat/ultrasound (thermosonication) on the thermal degradation kinetics of vitamin $\mathrm{C}$ in watercress (Nasturtium officinale) was studied in the temperature range of 82.5 to $92.5{ }^{\circ} \mathrm{C}$. First order reaction kinetics adequately described the vitamin $\mathrm{C}$ losses during both blanching processes.

The activation energies and the reaction rates at $87.5^{\circ} \mathrm{C}$ for heat $(\mathrm{H})$ and thermosonication $(\mathrm{Ts})$ treatments were, respectively, $E_{\mathrm{a}_{\text {vic }}}=150.47 \pm 42.81 \mathrm{~kJ}$ $\mathrm{mol}^{-1}$ and $E_{\mathrm{a}_{\text {vic }}}=136.20 \pm 60.97 \mathrm{~kJ} \mathrm{~mol}^{-1}$, and $k_{87.5}{ }^{\circ} \mathrm{CvitC}_{\mathrm{H}}=0.75 \pm 0.10 \mathrm{~min}^{-1}$ and $k_{87.5}{ }^{\circ} \mathrm{CvitC}_{\mathrm{Ts}}=0.58 \pm 0.11 \mathrm{~min}^{-1}$. No significant differences $(P>0.05)$ were detected between both treatments. The thermosonication treatment was found to be a better blanching process, since it inactivates watercress peroxidase at less severe blanching conditions and consequently retains vitamin $\mathrm{C}$ content at higher levels. The present findings will help to optimise the blanching conditions for the production of a new and healthy frozen product, watercress, with heat and a new blanching process methodology.
\end{abstract}

Industrial relevance: Thermosonication blanching can be useful since it reduces processing times, and consequently minimizes the adverse effects of heating on watercress quality. This new application will provide good material, in terms of vitamin $\mathrm{C}$, for further processes, and can be an excellent alternative to the traditional heat treatment.

\section{Introduction}

Watercress (Nasturtium officinale) is a hardy perennial herb of the family Cruciferae (mustard family) that grows in and around water. It has an essential range of minerals and vitamins and beneficial phytochemicals. Normally, it is commercialised in fresh and consumed in salads, soups and other recipes. Its short shelf life of nearly 7 days could be extended through freezing, allowing a longer period for distribution and storage.

Vegetables are a major source of ascorbic acid (AA), a nutrient that besides its vitamin action is valuable for its antioxidant effect, stimulating the immune system and other health

\footnotetext{
* Corresponding author. Tel.: +351 22 5580058; fax: +351 225090351. E-mail addresses: rcruz@ualg.pt (R.M.S. Cruz),mvieira@ualg.pt (M.C. Vieira), clsilva@esb.ucp.pt (C.L.M. Silva).
}

benefits. During processing, distribution and storage of frozen vegetables, ascorbic acid oxidizes to dehydroascorbic acid (DHAA), which retains vitamin $\mathrm{C}$ activity. Afterwards, it can be irreversibly hydrolyzed to 2,3-diketogulonic acid (DKGA), which possesses no biological activity. This last oxidation step is found to be much more temperature sensitive than the oxidation of ascorbic acid to dehydroascorbic acid (Belitz \& Grosch, 1999; Cooke \& Moxon, 1981; Esteve, Farré, Frigola, \& GarciaCantabella, 1997; Giannakourou \& Taoukis, 2003; Karhan, Aksu, Tetik, \& Turhan, 2004; Tannenbaum, 1976; Vieira, Teixeira, \& Silva, 2000).

Vitamin $\mathrm{C}$ is the least stable of all vitamins and is easily destroyed during processing and storage. The rate of destruction is increased by the action of metals, especially copper and iron, and enzymes. Availability of oxygen, prolonged heating in the presence of oxygen and exposure to light are all harmful factors 
to vitamin C content of foods (Deman, 1990). When oxygen is present, the contribution of the anaerobic degradation to the total vitamin $\mathrm{C}$ loss is small or not noticeable, compared to the aerobic degradation which has a much higher degradation rate (Villota \& Hawkes, 1992).

Enzymes containing copper or iron in their prosthetic groups are efficient catalysts of vitamin $\mathrm{C}$ decomposition. The most important enzymes of this group are ascorbic acid oxidase, cytochrome oxidase, phenolase and peroxidase. The severity of processing conditions can often be judged by the percentage of vitamin C that has been lost (Deman, 1990).

Some studies have been reported on the degradation of vitamin $\mathrm{C}$ in thermally processed fruits and vegetables like grapefruit juice (Saguy, Kopelman, \& Mizrahi, 1978), orange juice (Johnson, Braddock, \& Chen, 1995), lime, lemon, grapefruit and tangerine (Alvarado \& Viteri, 1989), cupuaçu nectar (Vieira et al., 2000), tomatoes (Dewanto, Wu, Adom, \& Liu, 2002), green asparagus (Esteve, Frígola, Martorell, \& Rodrigo, 1999), amla (Nisha, Singhal, \& Pandit, 2004), drumstick (Bineesh, Singhal, \& Pandit, 2005) and strawberry products (Castro, Teixeira, Salengke, Sastry, \& Vicente, 2004). However, few works have been reported on kinetic data for vitamin $\mathrm{C}$ degradation in leafy vegetables during thermal processing.

The application of heat treatment is the most common method for stabilizing foods, because of its capacity to destroy microorganisms and inactivate enzymes. However, since heat can impair as well many organoleptic properties and reduce the contents or bioavailability of some nutrients, there is a growing interest in searching for new technologies able to reduce the intensity of the heat treatments needed for food preservation (López, Sala, Fuente, Condón, Raso, \& Burgos, 1994).

Over the years, researchers have optimised time/temperature profiles to minimise the exposure of food to heat. Further, the newer process technologies may have the potential to reduce or even eliminate heat exposure. Some of these processes are not new, but have recently made significant advances towards commercialisation (Vikram, Ramesh, \& Prapulla, 2005).

The use of ultrasound in processing creates novel and interesting methodologies, which are often complementary to classical techniques. It has been proven to be particularly useful in sterilisation, extraction, freezing and filtration processes, providing reduced processing times and increased efficiency (Mason, Paniwnyk, \& Lorimer, 1996).

The thermosonication is a good alternative to the heat treatment, since it is in favour of less severe heat blanching conditions. Previous work demonstrated that thermosonication is more effective in watercress peroxidase inactivation (Cruz, Vieira, \& Silva, 2006) and green colour enhancement (Cruz, Vieira, \& Silva, 2007).

Since there are few research studies on the thermal degradation of vitamin C in leafy vegetables (Bineesh et al., 2005; Negi \& Roy, 2000), and none at all for watercress thermosonication blanching, the objective of this work was to determine the degradation kinetics of vitamin $\mathrm{C}$ in watercress with a combined method of heat and ultrasound. Thus, the findings will help to optimise the design of watercress blanching conditions.

\section{Materials and methods}

\section{Raw material}

Raw watercress ( $N$. officinale) was kindly supplied from a local producer. The leaves were selected, washed thoroughly and analyzed within $24 \mathrm{~h}$.

\section{Thermal and thermosonication blanching processes}

Heat treatments were carried out with temperatures ranging from 82.5 to $92.5{ }^{\circ} \mathrm{C}$, with different times of exposure. Each watercress sample $(3 \mathrm{~g})$ was processed in individual conical flasks with $100 \mathrm{ml}$ of distilled water, in a water bath Grant W14.

The blanching vessel temperature was monitored with a thermocouple in order to control the blanching water at the desired temperature. Sample's weight and blanching water volume were controlled for good experimental reproducibility.

The combination of heat/ultrasound was applied to the watercress for the same range of temperatures. The samples were blanched with an ultrasound horn (Coleparmer V1A; $13 \mathrm{~mm}$ dia) at $20 \mathrm{kHz}$, and an ultrasound generator (Coleparmer 4710 Series) radiating $50 \%$ of power $(125 \mathrm{~W})$. The blanching water volume for both treatments was adjusted for the ultrasound horn capacity in order to maintain the same processing conditions.

After each treatment, the samples were cooled in an iced water bath. The experiments were run in triplicate (Cruz et al., 2006).

\section{Vitamin $\mathrm{C}$ analysis by reversed phase ion interaction high performance liquid chromatography}

Ascorbic acid (AA) (Riedel-de Haën) content was determined based on a method previously reported (Zapata \& Dufour, 1992), by HPLC UV detection using isoascorbic acid (IAA) (Fluka) as internal standard. Dehydroascorbic acid (DHAA) (Sigma) was as well detected as fluorophore 3-(1,2-dihydroxyethyl)furo[3,4-b] quinoxaline-1-one (DFQ), after pre-column derivatization with 1,2-phenylenediamine dihydrochloride (OPDA) (Sigma).

For the mobile phase, $13.61 \mathrm{~g}$ of potassium dihydrogen phosphate (Merck) and $3.64 \mathrm{~g}$ of cetrimide (Fluka) were added to 21 of methanol (Merck, LiChrosolv)-ultrapure water $(5: 95, \mathrm{v} / \mathrm{v})$. The eluent was filtered in a $0.45 \mu \mathrm{m}$ membrane (Macherey-Nagel, Porafil) and degassed in an ultrasonic bath for $15 \mathrm{~min}$. The HPLC system consisted of a controller (LKB-2152, Bromma), a solvent pump (LKB-2150, Bromma), an injection valve with a $20 \mu \mathrm{l}$ sample loop, a guard pre-column (Macherey-Nagel, Chromcart Nucleosil 100-10 C18) followed by a reversed phase column (Macherey-Nagel, Chromcart 100-10 Nucleosil, 250×4.6 mm), and an UV detector (LKB-2153, Bromma).

After heat and thermosonication treatments, each sample ( $3 \mathrm{~g})$ was homogenised with an Ultra-turrax (IKAT25 Janke \& Kunkel) in $20 \mathrm{ml}$ of methanol-ultra pure water $(5: 95, \mathrm{v} / \mathrm{v})$ through $5 \mathrm{~min}$ at $8000 \mathrm{rpm}$. Each sample $(5 \mathrm{ml})$ was transferred to a $20 \mathrm{ml}$ volumetric flask and $1 \mathrm{ml}$ of IAA standard solution $(0.03 \mathrm{~g} / 50 \mathrm{ml})$ was added. The $\mathrm{pH}$ was adjusted with $\mathrm{HCl}$ (Merck) to obtain final values between 2.20 and 2.45 . The volume was completed to $20 \mathrm{ml}$ with methanol-ultra pure water $(5: 95, \mathrm{v} / \mathrm{v})$. The content was 

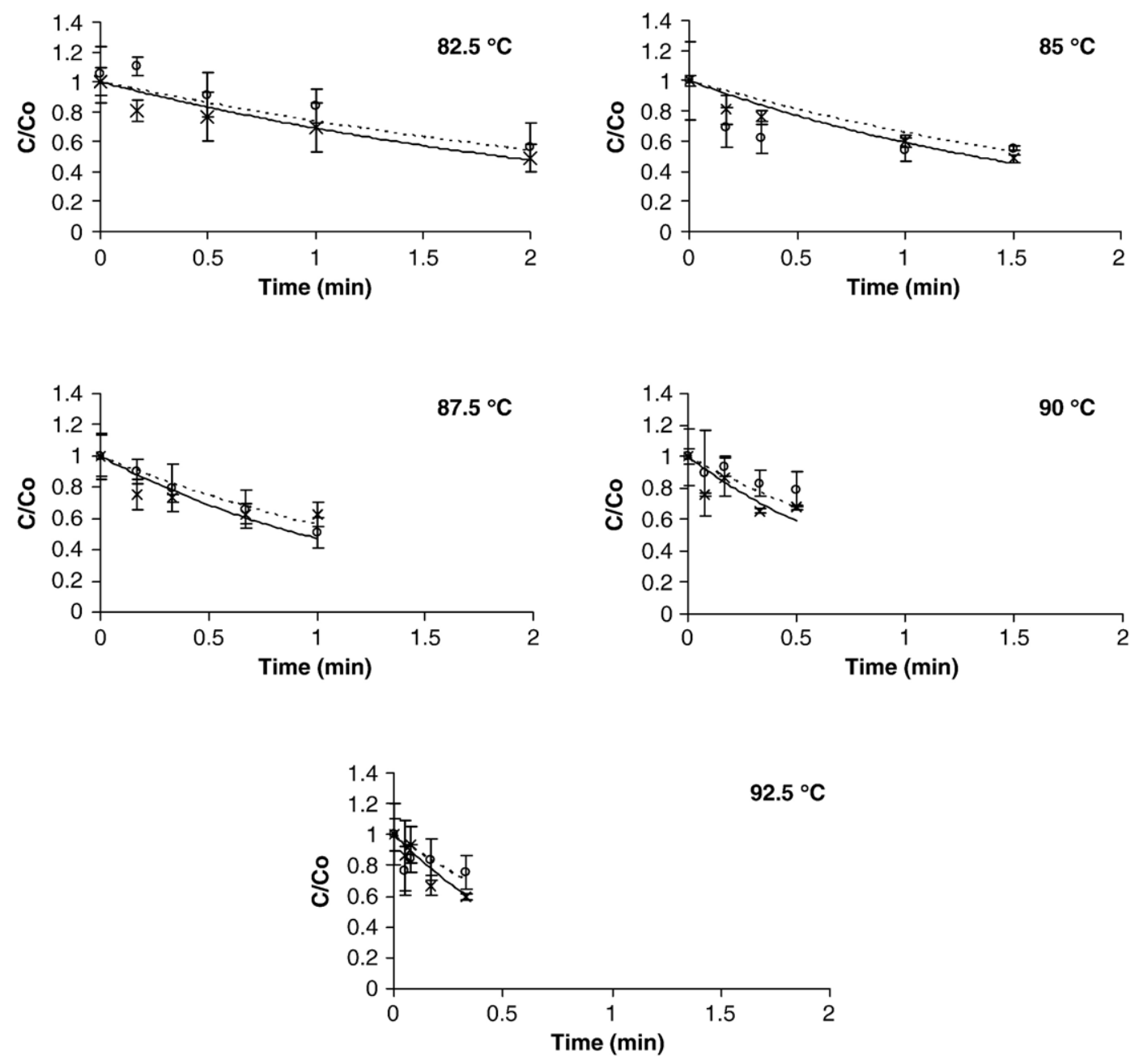

Fig. 1. Effect of temperature, ultrasound and time on watercress vitamin $\mathrm{C}$, in the temperature range of 82.5 to $92.5^{\circ} \mathrm{C}$ : (x) experimental values with heat blanching processes; (-) model predicted values for heat blanching processes; (o) experimental values with thermosonication blanching processes; (---) model predicted values for thermosonication blanching processes. Bars represent mean \pm standard deviation.

centrifuged (Sigma $3 \mathrm{~K} 20$ ) for $5 \mathrm{~min}$. at $8.720 \times g$ and $4{ }^{\circ} \mathrm{C}$. Afterwards, $3 \mathrm{ml}$ were transferred to another tube with $1 \mathrm{ml}$ of OPDA (Sigma) $(0.03 \mathrm{~g} / 50 \mathrm{ml})$ daily prepared and maintained in dark. The mixture was then vortexed and placed in dark at room temperature for $40 \mathrm{~min}$. Then the mixture was filtered in a $0.45 \mu \mathrm{m}$ membrane (Millipore), the first millilitre was discarded and $20 \mu \mathrm{l}$ were injected in the HPLC. The wavelength detector was set to $348 \mathrm{~nm}$ and after elution of DHAA, the wavelength was shifted to $262 \mathrm{~nm}$ for AA and IAA detection.

\section{Kinetics modelling}

Vitamin C in watercress was considered to follow first order degradation kinetics:

$$
\frac{C}{C_{0}}=e^{-k t}
$$

where $C_{0}$ is the initial vitamin $\mathrm{C}$ concentration at time equal to zero, $C$ is the content at time $t$, blanching time is represented by $t$, and $k$ is the reaction rate. The vitamin $\mathrm{C}$ final value was assumed to be the sum of the two biological active forms (ascorbic and dehydroascorbic acids). In order to minimise differences in watercress initial content, the experimental data were standardised (dividing each batch samples result by the corresponding initial concentration).

The reaction rate temperature dependence followed the Arrhenius behaviour:

$$
k=k_{r e f} e^{\left[-\frac{E a}{R}\left(\frac{1}{T}-\frac{1}{T_{\text {ref }}}\right)\right]}
$$

where $k_{\text {ref }}$ is the reaction rate at the reference temperature, $E_{\mathrm{a}}$ the activation energy, $R$ the universal gas constant, $T$ the absolute temperature and $T_{\text {ref }}$ the reference temperature.

By substitution, Eq. (1) can be expressed as

$\frac{C}{C_{0}}=e^{\left\{-k_{\text {ref }} e^{\left[-\frac{E_{a}}{R}\left(\frac{1}{T}-\frac{1}{T_{\text {ref }}}\right)\right]}\right\}}$ 
Experimental data points were normalised, dividing the vitamin $\mathrm{C}$ content by the corresponding initial value at time zero, before any processing. A one step non-linear regression was performed, fitting Eq. (3) to the normalised vitamin C experimental data (Arabshahi \& Lund, 1985). The reaction rate, at reference temperature, and activation energy were estimated using the statistical software STATA version 6.0 (Stata Corporation, 1999). For the parameters estimation, all the measurements were used, thus taking into account the samples variability. The reference temperature used was the mean value of the range considered (i.e. $T_{\text {ref }}=87.5^{\circ} \mathrm{C}$ ), aiming at improving parameters' estimation. Parameters' precision was evaluated by confidence intervals at $95 \%$, and the quality of the regression was assessed by the coefficient of determination $\left(R^{2}\right)$, and randomness and normality of residuals, thus allowing best model selection.

\section{Results and discussion}

Watercress samples presented an initial value of $50.40 \pm 5.77 \mathrm{mg}$ vitamin $\mathrm{C} 100 \mathrm{~g} \mathrm{fw}^{-1}$, which is in the same range of other reported values (62 $\mathrm{mg} 100 \mathrm{~g} \mathrm{fw}^{-1}$, (Holland, Unwin, \& Buss, 1991)) and confirms watercress as a good source of this nutrient.

Fig. 1 shows vitamin $\mathrm{C}$ degradation for both treatments, with no evidence of a broken line, which would imply the existence of two different degradation rates. Therefore, it seems that the anaerobic pathway was not followed, since the experiments were run in an opened blanching vessel, ensuring the presence of oxygen throughout the duration of all the blanching treatments.
Table 1

Published vitamin $\mathrm{C}$ activation energies $\left(E_{a}\right.$ 's) for different heating processes

\begin{tabular}{lll}
\hline Heating process & $E_{a}\left(\mathrm{~kJ} \mathrm{~mol}^{-1}\right)$ & Reference \\
\hline Conventional & 115.3 & Saguy et al., 1978 \\
& $38.9-46.5$ & Johnson et al., 1995 \\
& 52.8 & Lima, Heskitt, Burianek, Nokes, \\
& & and Sastry, 1999 \\
Ohmic & 52.3 & Lima et al., 1999 \\
& 29.3 & Assiry, 1996 \\
\hline
\end{tabular}

The treatments caused a vitamin $\mathrm{C}$ reduction of 40 to $60 \%$ to the fresh product value and its degradation was faster at higher temperatures, as expected, since this vitamin is thermolabile. Previous studies on savoy beet, amaranth and fenugreek leaves reported the same effect with hot water blanching (Negi \& Roy, 2000). Many studies indicate that the vitamin $C$ content loss during blanching can be attributed to the fact that this vitamin is very soluble in water (occurrence of the leaching phenomenon) and is not stable at high temperatures (Lee \& Kader, 2000; Lyimo, Nyagwegwe, \& Mnkeni, 1990; Nagy \& Smooth, 1977; Oboh, 2005). The watercress vitamin $C$ could have been washed away by the blanching water, however, since processing times used in this study were very short (maximum $2 \mathrm{~min}$ ), the reduction of this vitamin was probably mainly due to the heat effect.

The results showed no significant differences $(P>0.05)$ between heat and thermosonication treatments. Vitamin $\mathrm{C}$ degradation followed first order kinetics for both conventional and thermosonication treatments. According to many authors (Castro et al., 2004; Esteve et al., 1999; Nisha et al., 2004;
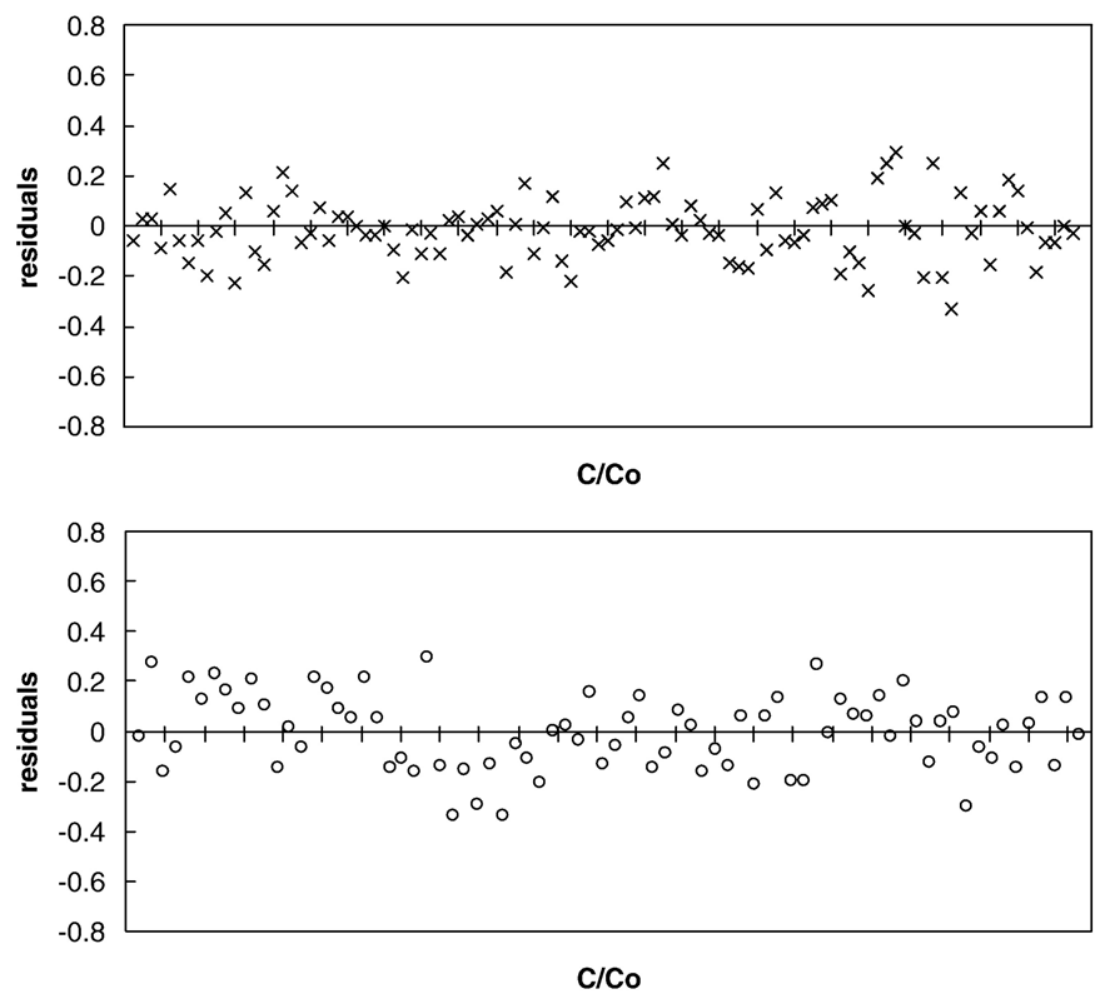

Fig. 2. Plot of residuals for $\mathrm{C} / \mathrm{Co}$ experimental data against model predicted values: $(\mathrm{x})$ heat blanching process; $(\mathrm{O})$ thermosonication blanching process. 
Vikram et al., 2005; Villota \& Hawkes, 1992), for a wide number of foodstuffs vitamin $\mathrm{C}$ degradation appears to follow first order kinetics, independently of the pathway followed.

The rate constants dependence on temperature followed an Arrhenius behaviour (Eq. (2)). The activation energies and the reaction rates at the reference temperature of $87.5{ }^{\circ} \mathrm{C}$ were, respectively, $E_{\mathrm{avitC}_{\mathrm{H}}}=150.47 \pm 42.81 \mathrm{~kJ} \mathrm{~mol}^{-1}$ and $E_{\mathrm{avitC}}=$ $136.20 \pm 60.97 \mathrm{~kJ} \mathrm{~mol}^{-1}$, and $k_{87.5}{ }^{\circ} \mathrm{CvitC}_{\mathrm{H}}=0.75 \pm 0.10 \mathrm{~min}^{-1}$ and $k_{87.5}{ }^{\circ} \mathrm{CvitC}_{\mathrm{Ts}}=0.58 \pm 0.11 \mathrm{~min}^{-1}$.

Fig. 2 presents the residuals plot, with no defined pattern, meaning that the model is adequate to the experimental data. This is also corroborated by the high coefficients of determination obtained for both blanching treatments $\left(R_{\mathrm{vit}_{\mathrm{H}}}^{2}=0.98 ; R_{\mathrm{vitC}_{\mathrm{Ts}}}^{2}=0.97\right)$.

Previous studies reported activation energy values for vitamin $\mathrm{C}$ degradation in foodstuffs of 65 to $160 \mathrm{~kJ} \mathrm{~mol}^{-1}$ (Hallström, Skjöldebrand, \& Trägårdh, 1988) and 7.54 to $125.6 \mathrm{~kJ} \mathrm{~mol}^{-1}$ (Lee \& Labuza, 1975).

Furthermore, research studies using different heating methods reported also values within the range of those obtained for watercress (Table 1). Moreover, in a study with manothermosonication (Vercet, Burgos, \& López-Buesa, 2001) the results demonstrated that manothermosonication did not affect significantly the nutrient content when compared with heat treatment. Nevertheless, the results are always dependent on the experimental set up (e.g. combination of time and temperature) as well as on the raw material used.

\section{Conclusion}

The thermosonication is a good alternative to the thermal treatment, since it is in favour of less severe heat blanching conditions. Previous work demonstrated that thermosonication is more effective in watercress peroxidase inactivation (Cruz et al., 2006). In order to produce the same degree of peroxidase inactivation $\left(90 \%\right.$ reduction), for example at $90{ }^{\circ} \mathrm{C}$, the heat blanching requires 70 seconds, that is about 14 -fold the processing time of the thermosonication treatment $(5 \mathrm{~s})$. This huge difference can lead to a higher retention of vitamin $\mathrm{C}$ in the thermosonication treatment (about 94\%) as compared to heat blanching, which reduces the content to $29 \%$.

The vitamin $\mathrm{C}$ losses due to processing are of great concern and this new pre-treatment will allow good vitamin $\mathrm{C}$ preservation, and consequently better raw material for further freezing processes. These studies are important to predict quality losses during thermal processing, even more when there is a lack of studies on the vitamin $\mathrm{C}$ thermal degradation kinetics in green vegetables.

The present findings will help to optimise the design of watercress blanching conditions with heat and thermosonication.

$\begin{array}{ll}\text { Symbols } & \\ C & \text { Vitamin C content }\left(\mathrm{mg} 100 \mathrm{~g} \mathrm{fw}^{-1}\right) \\ E_{a} & \text { Activation energy }\left(\mathrm{kJ} \mathrm{mol}{ }^{-1}\right) \\ k & \text { Reaction rate }\left(\mathrm{min}^{-1}\right) \\ \mathrm{R} & \text { Universal gas constant }\left(8.314 \mathrm{~J} \mathrm{~mol}^{-1} \mathrm{~K}^{-1}\right) \\ \mathrm{t} & \text { Time (min) } \\ \mathrm{T} & \text { Absolute temperature }(\mathrm{K})\end{array}$

\section{Subscripts}

$\mathrm{H} \quad$ Relative to heat blanching

ref At the reference temperature

Ts Relative to thermosonication blanching

vitC Relative to vitamin $\mathrm{C}$

$87.5^{\circ} \mathrm{C}$ At the reference temperature of $87.5^{\circ} \mathrm{C}$

$0 \quad$ Initial value at time equal to zero

\section{Acknowledgments}

The author Rui M. S. Cruz gratefully acknowledges his Ph.D. grant SFRH/BD/9172/2002 to Fundação para a Ciência e a Tecnologia (FCT) from Ministério da Ciência e do Ensino Superior. The authors thank the Vitacress Company for supplying the raw watercress.

\section{References}

Alvarado, J. D., \& Viteri, N. P. (1989). Effect of temperature on the aerobic degradation of vitamin $\mathrm{C}$ in citric fruit juices. Archives Latinoamerican Nutrition, 39, 601-612.

Arabshahi, A., \& Lund, D. B. (1985). Considerations in calculating kinetic parameters from experimental data. Journal of Food Process Engineering, 7, 239-251.

Assiry, A. (1996). Effect of ohmic heating on the degradation kinetics of ascorbic acid. Ph.D. thesis, The Ohio State University.

Belitz, H., \& Grosch, W. (1999). Vitamins. Food Chemistry (pp. 383-387). (2nd ed.). Germany: Springer-Verlag.

Bineesh, N. P., Singhal, R. S., \& Pandit, A. B. (2005). A study on degradation kinetics of ascorbic acid in drumstick (Moringa olifera) leaves during cooking. Journal of the Science of Food and Agriculture, 85, 1953-1958.

Castro, I., Teixeira, J. A., Salengke, S., Sastry, S. K., \& Vicente, A. A. (2004). Ohmic heating of strawberry products: electrical conductivity measurements and ascorbic acid degradation kinetics. Innovative Food Science and Emerging Technologies, 5, 27-36.

Cooke, J., \& Moxon, R. (1981). Detection and measurement of vitamin C. In J. Counsell \& D. Hornig (Eds.), Vitamin C Ascorbic Acid (pp. 167-168). England: Applied Science Publishers.

Cruz, R. M. S., Vieira, M. C., \& Silva, C. L. M. (2006). Effect of heat and thermosonication treatments on peroxidase inactivation kinetics in watercress (Nasturtium officinale). Journal of Food Engineering, 72(1), 8-15.

Cruz, R. M. S., Vieira, M. C., \& Silva, C. L. M. (2007). Modelling kinetics of watercress (Nasturtium officinale) colour changes due to heat and thermosonication treatments. Innovative Food Science and Emerging Technologies, 8(2), 244-252.

Deman, J. (1990). Principles of food chemistry (pp. 350-351). (2nd ed.). New York: Van Nostrand Reinhold.

Dewanto, V., Wu, X., Adom, K. K., \& Liu, R. H. (2002). Thermal processing enhances the nutritional value of tomatoes by increasing total antioxidant activity. Journal of Agricultural and Food Chemistry, 50, 3010-3014.

Esteve, M. J., Farré, R., Frigola, A., \& Garcia-Cantabella, J. M. (1997). Determination of ascorbic and dehydroascorbic acids in blood plasma and serum by liquid chromatography. Journal of Chromatography B: Biomedical Sciences and Applications, 688, 345-349.

Esteve, M. J., Frígola, A., Martorell, L., \& Rodrigo, C. (1999). Kinetics of green asparagus ascorbic acid heated in a high-temperature thermoresistometer. Zeitschrift fur Lebensmittel-Unterschung und -Forschung A, 208, 144-147.

Giannakourou, M. C., \& Taoukis, P. S. (2003). Kinetic modelling of vitamin C loss in frozen green vegetables under variable storage conditions. Food Chemistry, 83, 33-41. 
Hallström, B., Skjöldebrand, C., \& Trägårdh, C. (1988). Classification and characterization of foodstuffs. Heat Transfer and Food Products (pp. 26). England: Elsevier applied science.

Holland, B., Unwin, I., \& Buss, D. (1991). Vegetables, herbs and spices. The composition of Foods. Fifth supplement to McCance and Widdowson's. The Royal Society of Chemistry and Ministry of Agriculture Fisheries and Food (pp. 109). UK: Bath Press.

Johnson, J. R., Braddock, R. J., \& Chen, C. S. (1995). Kinetics of ascorbic acid loss and nonenzymatic browning in orange juice serum: Experimental rate constants. Journal of Food Science, 60(3), 502-505.

Karhan, M., Aksu, M., Tetik, N., \& Turhan, I. (2004). Kinetic modeling of anaerobic thermal degradation of ascorbic acid in rose hip (Rosa canina L.) pulp. Journal of Food Quality, 27, 311-319.

Lee, S. K., \& Kader, A. A. (2000). Preharvest and postharvest factors influencing vitamin C content of horticulture crops. Postharvest Biology and Technology, 20(3), 207-220.

Lee, S. H., \& Labuza, T. P. (1975). Destruction of ascorbic acid as function of water activity. Journal of Food Science, 40, 370-373.

Lima, M., Heskitt, B. F., Burianek, L. L., Nokes, S. E., \& Sastry, S. K. (1999). Ascorbic acid degradation kinetics during conventional and ohmic heating. Journal of Food Processing and Preservation, 23, 421-434.

López, P., Sala, F. J., Fuente, J. L., Condón, S., Raso, J., \& Burgos, J. (1994). Inactivation of peroxidase, lipoxygenase, and polyphenol oxidase by manothermosonication. Journal of Agricultural and Food Chemistry, 42, 252-256.

Lyimo, M. H., Nyagwegwe, S., \& Mnkeni, A. P. (1990). Investigations on the effect of traditional food processing, preservation and storage methods on vegetable nutrients: A case study in Tanzania. Plant Foods for Human Nutrition, 41, 53-57.

Mason, T. J., Paniwnyk, L., \& Lorimer, J. P. (1996). The uses of ultrasound in food technology. Ultrasonics Sonochemistry, 3, 253-260.

Nagy, S., \& Smooth, J. M. (1977). Temperature and storage effects on percent retention and percent U.S. recommended dietary allowances of vitamin $\mathrm{C}$ in canned single-strength orange juice. Journal of Agricultural and Food Chemistry, 25(1), 135-138.

Negi, P. S., \& Roy, S. K. (2000). Effect of blanching and drying methods on $\beta$-carotene, ascorbic acid and chlorophyll retention of leafy vegetables. Lebensmittel-Wissenschaft und-Technologie, 33, 295-298.

Nisha, P., Singhal, R. S., \& Pandit, A. B. (2004). A study on degradation kinetics of ascorbic acid in amla (Phyllanthus emblica L.) during cooking. International Journal of Food Sciences and Nutrition, 55, 415-422.

Oboh, G. (2005). Effect of blanching on the antioxidant properties of some tropical green leafy vegetables. Lebensmittel-Wissenschaft und Technologie, $38,513-517$.

Saguy, I., Kopelman, I. J., \& Mizrahi, S. (1978). Simulation of ascorbic acid stability during heat processing and concentration of grapefruit juice. Journal of Food Process Engineering, 2, 213-225.

Stata Corporation. (1999). Stata Statistical Software: Release 6.0 college station. Tannenbaum, S. (1976). Ascorbic acid. In O. Fennema (Ed.), Principles of Food Science. Part I. Food chemistry (pp. 477-544). (2nd ed.). New York: Marcel Dekker.

Vieira, M. C., Teixeira, A. A., \& Silva, C. L. M. (2000). Mathematical modeling of the thermal degradation kinetics of vitamin $\mathrm{C}$ in cupuaçu (Theobroma grandiflorum) nectar. Journal of Food Engineering, 43, 1-7.

Vercet, A., Burgos, J., \& López-Buesa, P. (2001). Manothermosonication of foods and food-resembling systems: Effect on nutrient content and nonenzymatic browning. Journal of Agricultural and Food Chemistry, 49, 483-489.

Vikram, V. B., Ramesh, M. N., \& Prapulla, S. G. (2005). Thermal degradation kinetics of nutrients in orange juice heated by electromagnetic and conventional methods. Journal of Food Engineering, 69, 31-40.

Villota, R., \& Hawkes, J. G. (1992). Reaction kinetics in food systems. In D. R. Heldman \& D. B. Lund (Eds.), Handbook of Food Engineering (pp. 39-144). New York: Marcel Dekker.

Zapata, S., \& Dufour, J. (1992). Ascorbic, dehydroascorbic and isoascorbic acid simultaneous determinations by reverse phase ion interaction HPLC. Journal of Food Science, 57, 506-511. 